\title{
THE SERUM TRYPTOPHANE-PERCHLORIC ACID REACTION AS A MEASURE OF TISSUE DESTRUCTION
}

\author{
BY \\ J. W. KEYSER \\ From the Department of Pathology and Bacteriology, Welsh National School of Medicine, \\ Cardiff
}

(RECEIVED FOR PUBLICATION JANUARY 20, 1950)

Increases in the level of serum polysaccharide have been found in a number of diseases (Lustig and Langer, 1931 ; Nilsson, 1937 ; Blix, Tiselius, and Svensson, 1941 ; Seibert, Seibert, Atno, and Campbell, 1947), in particular in tuberculosis and carcinoma, and it has been suggested (Seibert et al., 1947) that this increase is associated with tissue destruction- a conclusion in keeping with the finding of Lustig, Leiner, and Ernst (1937) that the carbohydrate content of the serum proteins in venous blood was generally higher than in arterial. In view of the possibility that this serum carbohydrate is derived from nucleic acid, Seibert, Pfaff, and Seibert (1948) applied to serum the tryptophane-perchloric acid (TA) reaction of Cohen (1944), when they found a significant increase in the reaction of cases of tuberculosis and several types of carcinoma. The nature of the reacting substance is unknown, but Seibert et al. have produced evidence suggesting that it is derived from proteins. This increased serum TA reaction might also be associated with tissue destruction.

It seemed of interest to test this hypothesis by applying the TA reaction to serum obtained from burned patients, in whom tissue destruction is known to occur, and where possible correlating the result with the excretion of nitrogenous substances in the urine. A preliminary report of the main findings has been published (Keyser, 1949).

\section{Methods}

Blood was obtained from the burned patients by venepuncture as soon as possible after admission to hospital, and thereafter at intervals. After clotting had occurred the serum was separated and kept frozen until the TA test could be performed. Under these conditions sera did not deteriorate for several weeks at least. Haemolysed specimens were not used for this test. The TA reaction was carried out as described by Seibert et al. (1948), except that the quantities of reagents (but not the proportions) were altered slightly for convenience.

Serum, $0.5 \mathrm{ml}$., was heated with $3.5 \mathrm{ml}$. $0.4 \%$ saline, $2.0 \mathrm{ml}$. $0.5 \%$ tryptophane, and $6 \mathrm{ml} .60 \%$ perchloric acid in a stoppered glass tube for exactly 10 minutes in a vigorously boiling water bath. After standing in ice-water for 40 minutes with occasional shaking the solution was filtered through a No. 5 Whatman filter paper and the extinction coefficient measured with the Spekker absorptiometer, using filter 
No. $6^{*}$ and a $1 \mathrm{~cm}$. cell. A reagent blank was run with each series of determinations. Where possible a serum blank was allowed for by diluting $0.5 \mathrm{ml}$. serum with $11.0 \mathrm{ml}$. saline and $0.5 \mathrm{ml}$. 2.5N.NaOH (Seibert, private communication). Results were recorded as (Spekker reading - blanks) $\times 100$, i.e.

$$
\text { E } 1 \text { cm. (corr.) } \times 100
$$

Readings were almost exactly proportional to the amount of serum taken for the test. Where transfusions of plasma, glucose, or saline were given, specimens of the transfusion fluids were subjected to the TA test: they were found not to give the reaction. Serum proteins were determined by the micro-Kjeldahl method. Non-protein nitrogen was determined in two cases by the method of King, Haslewood, and Delory (1937) or by Kjeldahl analysis of the Folin-Wu filtrate.

The TA test controls for Group 1 cases were eight children of about the same age who had been admitted for the investigation of minor complaints or the repair of defects such as cleft palate, but who were apparently normal in other respects. The controls for Group 2 were 10 normal adults.

In the case of the adult patients, 24-hour collections of urine were made, with chloroform as preservative, but owing to the absence of facilities for accurate metabolic work it is possible that some of these urine collections were in fact incomplete. Urine was tested for protein, sugar, and acetone bodies, and the nitrogenous constituents were determined as follows: total nitrogen by the Kjeldahl method, creatine and creatinine by Folin's (1914) method, and uric acid by the modification of the method of Benedict and Franke (1922), described by King (1946).

It was not always possible to follow up the cases for more than a few days owing to the patients' discharge from hospital.

\section{Technical Study of the TA Test}

Three main difficulties were encountered in applying the TA reaction. In the first place, since the identity of the reacting substance is unknown it is difficult to control the reaction except by reference to some arbitrary standard such as fructose, or by using specimens of serum as reference standards from time to time and also when changing from one batch of reagents to another. Secondly, it is impossible to carry out true serum blank determinations on account of the presence of tryptophane in the serum proteins. According to Seibert et al., variations in the natural colour of sera are allowed for by making control solutions of the sera in saline (Seibert et al., 1948) or in saline and $\mathrm{NaOH}$ (Seibert, private communication). Whether or not such a procedure gives a true serum blank, it was found in practice that many sera gave slightly opalescent solutions, even in the presence of $\mathrm{NaOH}$, and in such cases an arbitrary blank of $E_{1 \mathrm{~cm}} \times 100=1.5$ was subtracted from the test reading. (This was an average blank obtained with non-lipaemic sera: very little difference was found even with fairly deeply pigmented, but non-haemolysed. sera, provided that their solutions in saline and $\mathrm{NaOH}$ were clear.)

The third, and most serious, difficulty encountered was that the amounts of colour developed in the test varied from one batch of perchloric acid to another ; furthermore some batches gave high reagent blanks and poor colour development and were filter.

*Subsequent work showed that somewhat higher readings are obtained with the No. 7 
therefore rejected. (Only AnalaR* perchloric acid was used: it conformed to the AnalaR specifications for content of $\mathrm{HClO}_{4}$ and absence of chloride and chlorate.) These blank values cannot be allowed for simply by subtraction from the test reading, as the substance responsible for the blank value seems actually to inhibit colour development in the test, as is shown by some typical results given in Table I.

TABLE I

Inhibition of Colour Development by ReAGent Blank in the TA Test

\begin{tabular}{c|c|c|c||c|c|c}
\hline \multirow{2}{*}{ Perchloric Acid } & \multicolumn{3}{|c|}{ Serum JWK } & \multicolumn{3}{c}{ Serum TVB } \\
\cline { 2 - 6 } \cline { 5 - 7 } 1 & Test* $^{*}$ & Blank * $^{*}$ & Difference* $^{*}$ & Test* & Blank* $^{*}$ & Difference * \\
2 & 14.2 & 2.1 & 12.1 & 14.2 & 2.1 & 12.1 \\
& 16.8 & 8.2 & 8.6 & 17.5 & 8.2 & 9.3 \\
\hline
\end{tabular}

${ }^{*} \mathrm{E}_{1 \mathrm{~cm} .} \times 100$

In changing from one batch of reagents to another it is therefore necessary to check the amount of colour developed with each lot, using the same sera. In this way a correction may be applied, enabling results obtained with one lot of reagents to be related to those obtained with another.

It was confirmed that glucose gives a negligible amount of colour in the test. Urea, uric acid, and creatinine give no colour.

\section{Results in Burn Cases}

In this investigation the cases are divided into two groups (Cases 1-4 and 5-7) in which two different batches of perchloric acid were used. On account of a long delay, during which it was not possible to obtain satisfactory perchloric acid, the two groups are unrelated, but each group has its own series of appropriate normal values. The same batch of tryptophane was used throughout.

In spite of our criticisms of the TA test it is clear that after burning there is generally a more or less pronounced rise in the extinction coefficient in the TA test (Figs. 1 and 2), often up to values of the order met with in cancer. With the exception of Case 4, the TA extinction coefficient, at the peak of the rise, was $32 \%$ to $156 \%$ above the initial value, which may probably be taken as approximating to the normal, pre-burn level. (It is assumed that in Case 3, where it was not possible to obtain a blood specimen before the third day, the initial value would have been 7.4-see Fig. 1.) In one case, not shown in the figures, a single specimen of serum obtained from a child two days after burning gave a normal result (Case 4). Here it is possible that an initial slight rise was missed.

Spectrophotometric measurement of the absorption spectra of the TA reaction mixtures obtained with sera from two normal people, two burn cases, and two carcinoma cases showed the same absorption maxima (Fig. 3). For clarity, only one curve from each pair is shown in the figure.

* By the co-operation of Messrs. The British Drug Houses, Ltd., and Messrs. Hopkin and Williams, Ltd., we were able to obtain special batches of AnalaR perchloric acid which had been specially tested and shown to give satisfactory colour development. 


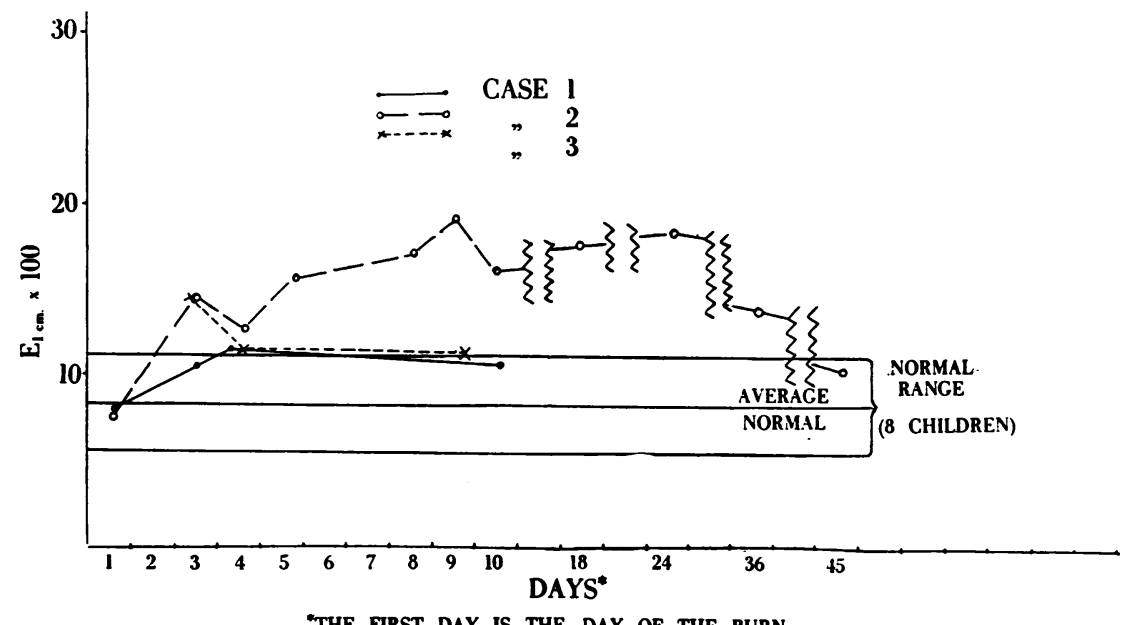

"THE FIRST DAY IS THE DAY OF THE BURN

FIG. 1.-Rise in extinction coefficient in TA test after burning (Group 1 cases).

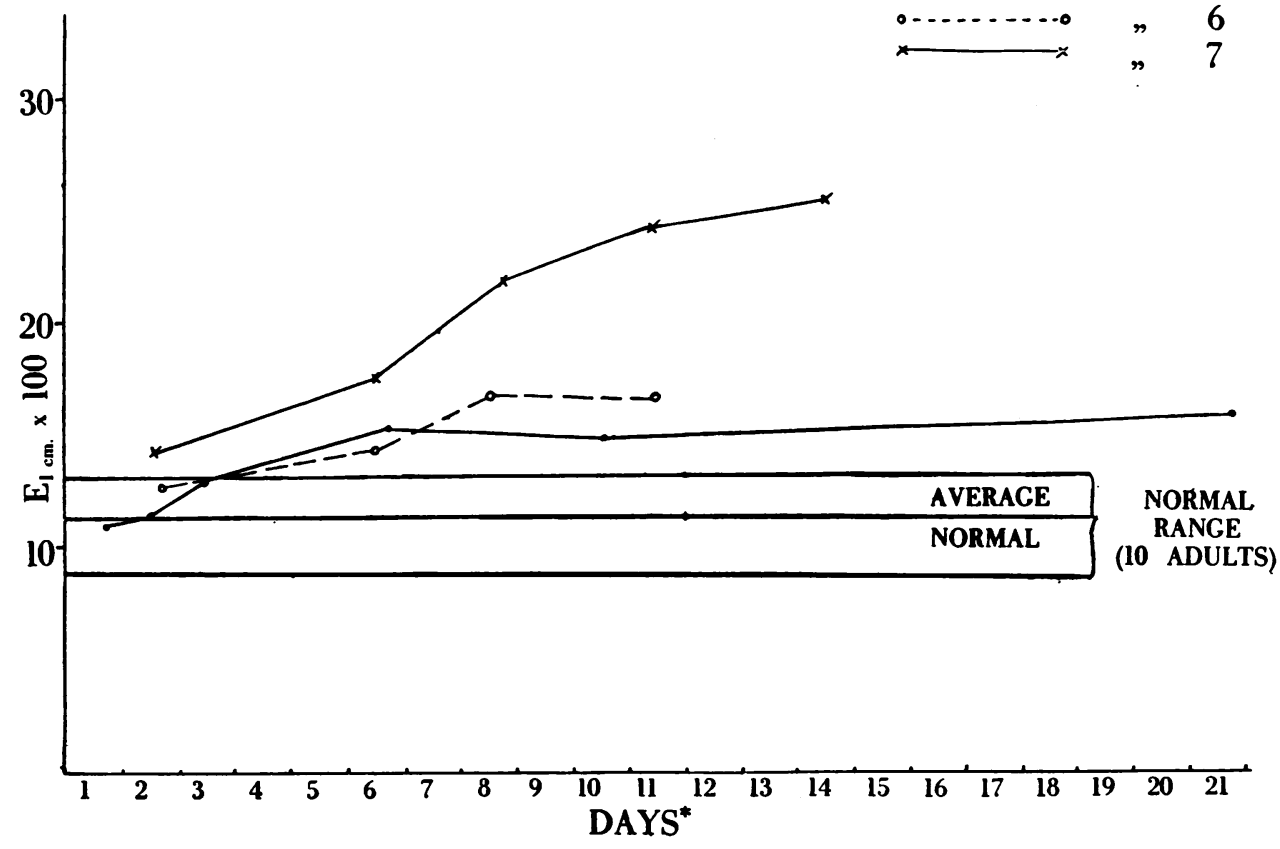

*THE FIRST DAY IS THE DAY OF THE BURN

Fig. 2.-Rise in extinction coefficient in TA test after burning (Group 2 cases). 


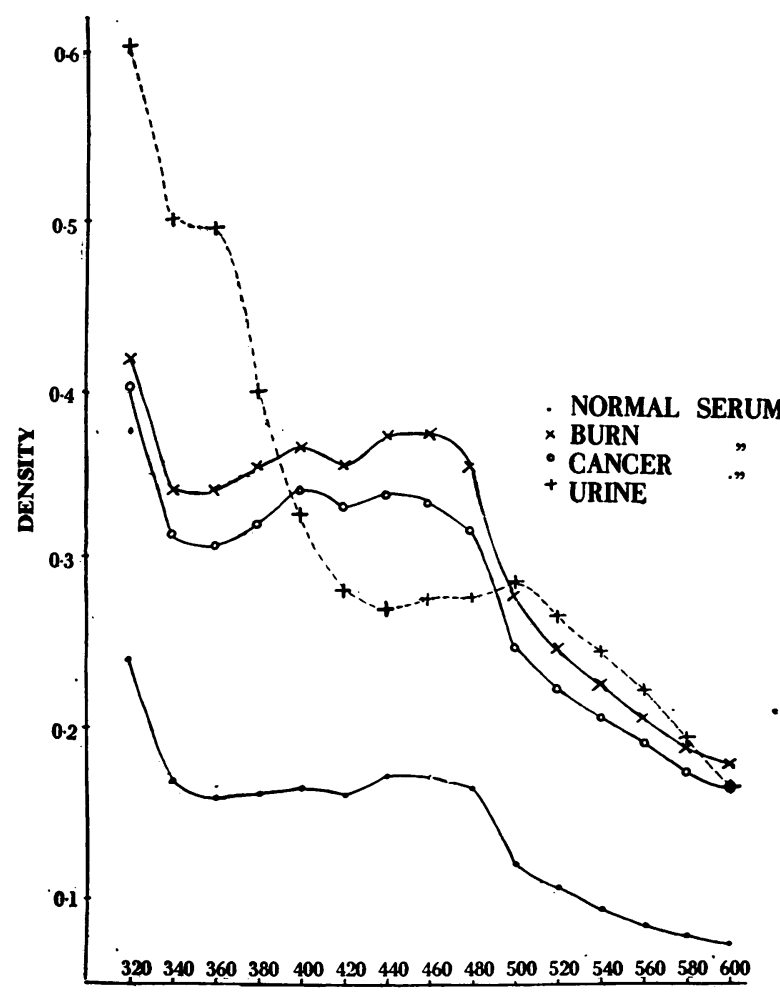

WAVELENGTH (Dp)
FIG. 3.-Absorption curves of reaction mixtures in TA test.

\begin{abstract}
Case Notes
The following notes give necessary clinical details. Serum protein and non-protein nitrogen values are given in Table II.
\end{abstract}

Case 1.-V. B., a girl of $2 \frac{1}{2}$ years, was admitted with scalds (second degree) extending from the interscapular region to the buttocks and on a small area of the left heel. The burned area was cleaned with "cetavlon" and treated with penicillin and sulphonamide powder. Transfusions included $400 \mathrm{ml}$. plasma, $500 \mathrm{ml}$. plasma-saline, and 1,000 $\mathrm{ml}$. plasma-glucose. Penicillin - was given $(50,000$ units threehourly) until the sixth day. Other drugs given were " nembutal," nepenthe, and chloral.

Case 2.-K. M., a girl aged 2 years, was admitted with first and second degree burns of the face, chest, and arms sustained when she fell on to an open fire and her clothes caught fire. The burns were treated with sulphonamide and penicillin powder. A total of $800 \mathrm{ml}$. plasma and $200 \mathrm{ml}$. glucose-saline was transfused. Penicillin was given $(25,000$ units three-hourly) until about the fortieth day, by which time the TA reaction had decreased to a nearly normal level. The temperature was barely above normal after the second day. Other drugs used were nepenthe, ephedrine, protargol (nasal drops), " nembutal," chloral.

Case 3.-L. P., a girl aged $2 \frac{1}{2}$ years, was admitted with first degree scalds of the chest and upper arms, and a few areas of second degree scalding, received two days previously. Penicillin was injected (50,000 units three-hourly) until the seventh day, but no plasma transfusions were given. The temperature was normal after about the second day. Nepenthe was also used in this case.

Case 4.-B. C., a boy of $3 \frac{1}{2}$ years, was admitted with burns of the chest (first degree with small areas of second). The TA test, performed two days later, gave a normal result.

Case 5.-G. C., a male adult, was admitted with second degree burns of the face, hands, and left thigh, caused by a petrol fire. The burns were treated with sulphonamide and penicillin powder, and systemic penicillin $(100,000$ units three-hourly) was given up to the twenty-fifth day. The patient's temperature was normal after the second day. Other drugs used in this case were morphine and atropine. 
TABLE II

Serum Protein Values in Cases $1,2,3,5,6$, and 7

\begin{tabular}{|c|c|c|c|}
\hline Case No. & Day* & $\begin{array}{l}\text { Serum Protein } \\
(\mathrm{g} . / 100 \mathrm{ml} .)\end{array}$ & $\begin{array}{c}\text { Non-protein N } \\
\text { (mg./100 ml.) }\end{array}$ \\
\hline 1 & $\begin{array}{r}1 \\
3 \\
10\end{array}$ & $\begin{array}{l}6.1 \\
7.3 \\
6.8\end{array}$ & $\bar{z}$ \\
\hline 2 & $\begin{array}{r}1 \\
3 \\
5 \\
9 \\
14 \\
45\end{array}$ & $\begin{array}{l}6.5 \\
6.7 \\
6.2 \\
6.5 \\
6.8 \\
6.9\end{array}$ & $\begin{array}{l}34 \\
26 \\
35 \\
32 \\
- \\
-\end{array}$ \\
\hline 3 & $\begin{array}{l}1 \\
6\end{array}$ & $\begin{array}{l}6.3 \\
5.8\end{array}$ & 二. \\
\hline 5 & $\begin{array}{l}1 \\
3 \\
6\end{array}$ & $\begin{array}{l}6.9 \\
6.5 \\
5.5\end{array}$ & $\bar{Z}$ \\
\hline 6 & $\begin{array}{r}2 \\
6 \\
8 \\
11\end{array}$ & $\begin{array}{l}6.8 \\
6.2 \\
6.9 \\
7.1\end{array}$ & $\begin{array}{l}= \\
=\end{array}$ \\
\hline 7 & $\begin{array}{r}2 \\
6 \\
8 \\
14\end{array}$ & $\begin{array}{l}6.0 \\
6.0 \\
6.2 \\
6.9\end{array}$ & $\begin{array}{l}42 \\
25 \\
32 \\
29\end{array}$ \\
\hline
\end{tabular}

* The day of the burn is taken as the first day.

Case 6.-D. C., a man aged 30, was admitted with second degree burns of face, ears, and hands, sustained in a gas explosion. "Cetavlon" was used to clean the burns, which were treated with penicillin and sulphonamide. Systemic penicillin $(100,000$ units three-hourly) was given up to the tenth day. The temperature was normal after the first day. No plasma was transfused. Morphine was also given after admission.

Case 7.-R. H., a man of 59, was admitted with extensive third degree burns of face, ears, and both hands, with second degree burns also. (This patient was injured in the same gas explosion as Case 6.) The usual treatment was given with " cetavlon," penicillin and sulphonamide, and intravenous plasma ; penicillin was given systemically up to the eighteenth day $(100,000$ units three-hourly). The temperature became normal after the twelfth day. The chief complication in this case was sepsis, and the principal accessory chronic disease was stated to be chronic bronchitis and emphysema.

\section{Discussion}

The observations reported are consistent with the view that the TA reaction provides a measure of tissue destruction.

With the exception of Case 7, all the patients were free from generalized infection, though even in Case 7 it is clear that there was a pronounced increase in the TA 
reaction from the second to the fourteenth day. This rise is unlikely to have been due to the bronchitis and emphysema already present, the first value obtained being only slightly above the upper normal level (see Fig. 2).

It is difficult to draw any conclusions from the urinary analyses, especially in view of the very small number of cases. Too much reliance cannot be placed on the figures for total amounts excreted, and the full results are therefore omitted from this account. It may be significant, however, that of the two cases (6 and 7) studied side by side, the more severely burned patient showed the greater excretion of creatine and total nitrogen as well as a more pronounced rise in TA reacting substance. Thus Case 6 excreted only about $45 \mathrm{mg}$. creatine from admission up to the eighth day, though there was then a slight increase, $83 \mathrm{mg}$. being excreted from the eighth to ninth days. Case 7, however, excreted about $900 \mathrm{mg}$. of creatine in the first five days.

Clark, Peters, and Rossiter (1945) and Croft and Peters (1945) found that after a severe burn rats showed a sharp rise in creatine excretion. Cuthbertson, McGirr, and Robertson (1939) in experiments on rats showed that fracture of the femur caused a definite loss of creatine in the urine that paralleled nitrogen excretion, and Cuthbertson (1936) reported similar findings in a study of human fractures. I (Keyser, 1947,1948 ) reported that three adult males with burns of 20,15 , and $7 \%$ of the body surface, respectively, excreted creatine in significant amounts, whereas four other adult males with burns of not more than $2 \frac{1}{2} \%$ of the body surface excreted little or none. The excretion of creatine appears to result from bodily injury and consequent tissue destruction. Creatinuria has been reported as occurring in normal healthy males (see, e.g., Hobson, 1939), though other workers, in extended studies, have failed to confirm this (Tierney and Peters, 1943).

Uric acid excretion, where measured, was within normal limits (Cases 5, 6, and 7).

A point of great interest is that Seibert $e$ al . (1948) found a correlation between the serum content of $a_{2}$-globulin and of TA-reacting material in their cases, while earlier workers (Perlmann, Glenn, and Kaufman, 1943 ; Chanutin and Gjessing, 1946) had reported a rise in the $a$-globulin fraction following experimental burns in animals. Indeed, there is some evidence that a rise of $a$-globulin in the serum is associated with tissue destruction, though this has recently been questioned by Marrack and Hoch (1949).

The possibility that the high TA values in our patients might be due to retention or to failure to metabolize the reacting substance cannot be excluded. The reaction mixture obtained with urine was therefore examined spectrophotometrically with a Beckman spectrophotometer with a view to measuring the excretion (if any) of TA substance. The curve differed from those obtained with serum (Fig. 3), showing that application of the reaction to urine did not provide a means of measuring the excretion of TA substance.

Another possibility that cannot be excluded is that the drugs administered, particularly penicillin, might have had some effect on the TA test. Penicillin itself did not give the colour reaction, but it is conceivable that some metabolic product might do so or that it might otherwise have some metabolic effect. However, in Case 2 the TA reaction had decreased almost to normal levels before penicillin injections had been discontinued. 


\section{Summary}

A critical study was made of the serum tryptophane-perchloric acid reaction.

Results obtained with six burn cases are consistent with the view that this reaction provides a measure of tissue destruction.

I wish to thank Mr. F. A. Ibbott for making the spectrophotometric measurements (by kind permission of Dr. H. McIlwain). I am grateful also to Dr. Florence Seibert for advice ; to many colleagues who provided me with clinical material, especially Dr. S. R. Elgood, Dr. G. H. Jenkins, and Mr. A. S. Aldis ; to Mr. J. B. Haycraft and Dr. A. G. Watkins for permission to publish details from the patients' case-notes ; to Professor J. Gough and Dr. A. Cochrane for their help.

\section{REFERENCES}

Benedict, S. R., and Franke, E. (1922). J. biol. Chem., 52, 387.

Blix, G., Tiselius, A., and Svensson, H. (1941). Ibid., 137, 485.

Chanutin, A., and Gjessing, E. C. (1946). Ibid., 165, 421.

Clark, E. J., Peters, R. A., and Rossiter, R. J. (1945). Quart. J. exp. Physiol., 33, 113.

Cohen, S. S. (1944). J. biol. Chem., 156, 691.

Croft, P. B., and Peters, R. A. (1945). Lancet, 1, 266.

Cuthbertson, D. P. (1936). Brit. J. Surg., 23, 505.

McGirr, J. L., and Robertson, J. S. M. (1939). Quart. J. exp. Physiol., 29, 13.

Folin, O. (1914). J. biol. Chem., 17, 469.

Hobson, W. (1939). Biochem. J., 33, 1425.

Keyser, J. W. (1947). Lancet, 1,217. (1948). Ann. Surg., 127, 605.

(1949). Nature, Lond., $164,889$.

King, E. J. (1946). Micro-analysis in Medical Biochemistry. 1st ed. London: Churchill. Haslewood, G. A. D., and Delory, G. E. (1937). Lancet, 1, 886.

Lustig, B., and Langer, A. (1931). Biochem. Z., 242, 320.

- Leiner, G., and Ernst, T. (1937). Z ges. exp. Med., 100, 492.

Marrack, J. R., and Hoch, H. (1949). J. clin. Path., 2, 161.

Nilsson, I. (1937). Biochem. Z., 291, 254.

Perlmann, G. E., Glenn, W. W. L., and Kaufman, D. (1943). J. clin. Invest., $22,627$.

Seibert, F. B., Seibert, M. V., Atno, A. J., and Campbell, H. W. (1947). J. clin. Invest., 26, 90.

- Pfaff, M. L., and Seibert, M. V. (1948). Arch. Biochem., 18, 279.

Tierney, N. A., and Peters, J. P. (1943). J. clin. Invest., 22, 599. 